\title{
Identities and Geographic Distributions of Phytophthora spp. Causing Root Rot of Red Raspberry in Chile
}

\author{
W. F. Wilcox, Department of Plant Pathology, Cornell University, New York State Agricultural Experiment Station, \\ Geneva, NY 14456; and B. A. Latorre, Facultad de Agronomía e Ingenería Forestal, Pontificia Universidad \\ Católica de Chile, Casilla 306-22, Santiago, Chile
}

\begin{abstract}
Wilcox, W. F., and Latorre, B. A. 2002. Identities and geographic distributions of Phytophthora spp. causing root rot of red raspberry in Chile. Plant Dis. 86:1357-1362.

Five identified and two unidentified Phytophthora spp. were isolated from diseased roots of dead or declining red raspberry (Rubus idaeus L.) plants sampled from 18 plantations along a $>1,000-\mathrm{km}$ north-south axis in Chile. The array of Phytophthora spp. isolated was strongly associated with geographical location. P. fragariae var. rubi was recovered from 75 and $60 \%$ of the plantations in the southern $\left(40^{\circ} 16^{\prime}\right.$ to $40^{\circ} 53^{\prime} \mathrm{S}$ latitude) and central $\left(34^{\circ} 35^{\prime}\right.$ to $37^{\circ} 23^{\prime} \mathrm{S}$ latitude) production sectors, respectively, but was not recovered from any plantation in the northern sector ( $32^{\circ} 43^{\prime}$ to $33^{\circ} 45^{\prime} \mathrm{S}$ latitude). Similarly, P. megasperma and P. gonopodyides were recovered from multiple plantations in the southern and central sectors but were not recovered in the northern sector. In contrast, P. cryptogea was recovered from $80 \%$ of the plantations in both the northern and central sectors but not from any plantation in the south, whereas $P$. citricola was isolated from diseased plants in all sectors. In subsequent pathogenicity trials, $P$. citricola, $P$. cryptogea, and an unidentified Phytophthora sp. were equally and highly virulent on 'Heritage' red raspberry in each of three greenhouse experiments. The other species were less virulent in the experiment when soil temperatures were highest (mean weekly maximum $=27.5^{\circ} \mathrm{C}$ ) relative to the other two experiments when temperatures were more moderate (mean weekly maxima of 19.9 and $23.7^{\circ} \mathrm{C}$ ). Isolates identified as $P$. cryptogea were very similar to P. cryptogea isolates recovered previously from kiwi fruit in Chile and from deciduous fruit trees in California with respect to morphological characters and electrophoretic banding patterns of soluble mycelial proteins. Using the same criteria, isolates identified as $P$. gonopodyides were very similar to isolates recovered earlier from deciduous fruit crops in New York, which previously were identified as $P$. cryptogea sensu lato but are hereby reclassified as $P$. gonopodyides.
\end{abstract}

In the country of Chile, red raspberry (Rubus idaeus L.) is a high-value export crop cultivated on approximately 7,250 ha across a range of diverse climatic zones. Commercial plantings extend $>1,000 \mathrm{~km}$ along a north-south axis, from the $\mathrm{V}$ Region (governmental administrative zone) north of Santiago to an area south of Osorno in the X Region. In 1993, Latorre and Muñoz (8) identified Phytophthora citricola Sawada and P. citrophthora (R. E. Sm. \& E. H. Sm.) Leonian as causes of a previously unidentified root rot and dieback of this crop in central Chile, recognizing the similarities between the disease they encountered and reports of Phytophthora root rot from other raspberryproducing regions of the world. In this regard, they suggested the possibility that other Phytophthora spp. also may be in-

Corresponding author: W. F. Wilcox

E-mail: wfw1@cornell.edu

Partial financial support of the study was provided by Fundación Andes Chile.

Accepted for publication 6 August 2002.

Publication no. D-2002-1015-03R

(c) 2002 The American Phytopathological Society volved in the root rot syndrome in Chile (i.e., in addition to $P$. citricola and $P$. citrophthora, at least eight named and several unidentified Phytophthora spp. have been shown to cause root rot on raspberries in North America, Europe, and Australia; 5,25). Of these, the most serious in terms of prevalence and virulence appears to be $P$. fragariae C. J. Hickman var. rubi Wilcox \& Duncan, also referenced in older literature as $P$. erythroseptica Pethybr. \& Laff. or as a "highly pathogenic" variant ("type 2") of $P$. megasperma Drechs. $(5,26)$. This species is thought to have originated in the cool climates near the Pacific coast of North America, whence it spread to the northeastern part of the continent (17) and throughout much of northern Europe $(4,5)$. However, it had not been reported from the Southern Hemisphere when the Chilean investigations (8) were concluded.

Whereas numerous Phytophthora spp. can cause death and decline of red raspberries, it is of practical importance to identify precisely which of these are responsible for the disease in particular locales. For example, most studies evaluating cultivar resistance to root rot have examined only $P$. fragariae var. rubi, although raspberry cultivars appear to exhibit differential lev- els of resistance to different Phytophthora spp. (25). Similarly, different Phytophthora spp. may show strikingly variable sensitivities to certain fungicides used for their control (3). Furthermore, efforts at pathogen exclusion, both regulatory and voluntary, may be influenced by the qualitative and quantitative presence of specific pathogens in an affected area.

Therefore, the objective of this study was to identify the Phytophthora spp. causing root rot throughout the varied raspberry-producing regions of Chile, in order to gain a clearer understanding of the etiology of the disease in this country. A brief summary of this work was published previously (21).

\section{MATERIALS AND METHODS}

Isolations. Eighteen commercial raspberry plantations were visited where farm advisors or managers had identified symptoms suggestive of Phytophthora root rot The northernmost of these was near Nogales $\left(32^{\circ} 43^{\prime} \mathrm{S}\right.$ latitude) in a semi-arid agricultural region typified by the production of subtropical fruit such as citrus and avocado, whereas the southernmost was near Purranque $\left(40^{\circ} 53^{\prime} \mathrm{S}\right.$ latitude) in a high-rainfall agricultural region typified by dairy farms and cool-climate crops such as potato. All were at relatively low altitudes. Three to eight symptomatic plants were sampled from each site, transported to the laboratory in an ice chest, and at least 12 diseased tissue pieces per root and crown system were plated on corn meal agar amended with six fungicides and antibiotics (i.e., ACMA selective medium; 8) as described previously $(8,17)$. Plates were incubated in the dark at $20^{\circ} \mathrm{C}$ and examined at 1- to 2-day intervals for the next 10 days. Hyphal tips of emerging Phytophthora colonies were transferred to corn meal agar (CMA) (Difco Laboratories, Detroit), then pure cultures were transferred to slants of this medium and stored until they were identified.

Identification of Phytophthora spp. All isolates were identified initially on the basis of standard cultural and morphological characters. Colony morphologies were determined after 4 days of growth in the dark at $24^{\circ} \mathrm{C}$ on both CMA and V8 juice agar (17) amended with rifampicin at 10 $\mathrm{mg} /$ liter plus sodium ampicillin (V8RA) at $250 \mathrm{mg} /$ liter. Growth responses to temperature were determined after 4 days of 
incubation on CMA (or 8 days on V8RA for isolates thought to be $P$. fragariae var. rubi) at increments of $3^{\circ} \mathrm{C}$, from 4 to $28^{\circ} \mathrm{C}$ and 30 to $36^{\circ} \mathrm{C}$ (17). Sporangia were produced from mycelial mats in saline solution (8) and from agar plugs in nonsterile soil extract (17), and morphologies and dimensions were determined. Production of gametangia was attempted by growing isolates on clarified V8 juice agar amended with thiamine, tryptophan, and $\beta$-sitosterol (CV8A; 17) medium for 3 to 6 weeks at $20^{\circ} \mathrm{C}$ in the dark. Subsequently, those not producing gametangia in single culture were paired with known $\mathrm{A}_{1}$ and $\mathrm{A}_{2}$ isolates of $P$. cinnamomi Rands under these same conditions.

Selected isolates identified as P. cryptogea, P. gonopodyides (Petersen) Buisman, and $P$. megasperma were studied further using sodium dodecyl sulfate-polyacrylamide gel electrophoretic (SDS-PAGE) profiles of soluble mycelial proteins; for $P$. cryptogea isolates, the electrophoretic activity of the malate dehydrogenase (MDH) isoenzyme also was examined from undissociated proteins. Mycelium was grown for $72 \mathrm{~h}$ at 20 to $23^{\circ} \mathrm{C}$ in carrot juice broth, washed three times with distilled water, and freeze dried in liquid nitrogen. Then, soluble proteins were extracted by grinding 2 to $3 \mathrm{~g}$ of the frozen mycelium with a mortar and pestle. Protein patterns and enzyme activity profiles were produced and analyzed subsequently, using previously described techniques (9).

Pathogenicity experiments. Pathogenicity experiments were conducted using the methods described previously (17). Briefly, 'Heritage' red raspberry plants produced via tissue culture techniques in soilless potting medium (Nourse Farms, Whatley, MA) were transplanted individually into 0.95 -liter containers filled with a pasteurized soil-vermiculite potting medium into which colonized-vermiculite inocula of individual Phytophthora sp. isolates had been incorporated at a rate of $2 \%$ by volume. Then, 2 weeks later and at 2-week intervals thereafter, all pots (except those for one of the two uninoculated check treatments) were flooded for a $48-\mathrm{h}$ period; otherwise, pots were watered daily. After 12 to 16 weeks, plants were removed from their pots, the root systems were washed, and the percentage of the root mass rotted plus the viability or mortality of the whole plant were determined visually for each of the five replicate plants per treatment. After arcsine transformation, root rot data were subjected to analysis of variance for a completely randomized design, and means were separated according to the Waller-Duncan $k$-ratio $t$ test (SAS version 6.12; SAS Institute, Cary, NC). Each of three repeats of the experiment was conducted in a temperature-moderated greenhouse in Geneva, NY, where supplemental light was provided as necessary to maintain a 16-h photoperiod. The individual runs of the experiment were conducted during different periods of the year, resulting in different ranges of temperatures for each. Soil temperatures were monitored throughout each run of the experiment by burying the temperature probe from a hygrothermograph (Belfort Instrument Co., Baltimore, MD) approximately 3 to $5 \mathrm{~cm}$ deep within a flat of potting medium in the same greenhouse. Maximum, minimum, and mean temperatures were determined weekly by averaging the daily recorded values (Table 1 ).

\section{RESULTS}

Identities and characteristics of Phytophthora spp. Phytophthora spp. were isolated from diseased roots of $72 \%$ of the sampled red raspberry plants, including at least one plant from each of the 18 plantations (Table 2). A subsample of these plants also was examined in a parallel study (10) investigating the utility of an enzyme-linked immunosorbent assay (ELISA) kit (Sigma-Aldrich, St. Louis) for detecting Phytophthora spp. in symptomatic tissues of various fruit plants. Within this subsample, each of the 38 plants from which we isolated the fungi also tested positive for Phytophthora spp. using the ELISA kit, whereas the test detected a Phytophthora sp. in five of the eight plants from which none was isolated.

Individual isolates were identified as $P$. citricola, $P$. cryptogea, $P$. fragariae var. rubi, $P$. gonopodyides, and $P$. megasperma. Additionally, an unidentified high-temperature heterothallic species (optimum = 28 to $33^{\circ} \mathrm{C}$, maximum $>36^{\circ} \mathrm{C}$; Fig. 1) and an unidentified homothallic species (optimum temperature $=19$ to $25^{\circ} \mathrm{C}$, maximum $<33^{\circ} \mathrm{C}$; Fig. 1), both of which produced nonpapillate sporangia, were each recovered from single locations. Isolates identi-

Table 1. Weekly soil temperatures $\left({ }^{\circ} \mathrm{C}\right)$ during greenhouse tests for pathogenicity of Phytophthora spp. isolated from symptomatic raspberry plants in Chile

\begin{tabular}{|c|c|c|c|c|c|c|}
\hline \multirow[b]{2}{*}{ Temperature $^{\mathrm{z}}$} & \multicolumn{2}{|c|}{ Experiment 1} & \multicolumn{2}{|c|}{ Experiment 2} & \multicolumn{2}{|c|}{ Experiment 3} \\
\hline & Range & Mean & Range & Mean & Range & Mean \\
\hline Maximum & $25.0-32.0$ & 27.5 & $17.5-23.0$ & 19.5 & $22.0-28.5$ & 24.4 \\
\hline Minimum & $18.5-22.5$ & 19.9 & $15.0-19.0$ & 16.5 & $17.5-24.0$ & 21.9 \\
\hline Average & $21.8-27.3$ & 23.7 & $16.3-21.0$ & 18.0 & $20.0-26.3$ & 19.4 \\
\hline
\end{tabular}

${ }^{\mathrm{z}}$ Values represent the weekly means for the maximum, minimum, and average $([\max +\min ] / 2)$ temperatures determined each day from the commencement of the experiment until its conclusion, using a temperature probe buried 3 to $5 \mathrm{~cm}$ deep in a flat of potting mix within the greenhouse. fied as $P$. citricola were similar to those described previously from raspberry in Chile (8) and New York (17). Isolates identified as $P$. megasperma also were similar to those described previously on raspberry (17) and others as belonging to the "Broad Host Range" subgroup of the species (6) with respect to oospore formation and size, sporangium morphology, colony morphology, and cardinal temperatures for growth (Fig. 1). Furthermore, all four Chilean raspberry isolates selected arbitrarily for further SDS-PAGE studies produced protein profiles that were virtually identical to those of $P$. megasperma isolates recovered from peach in New York (isolate NY 404) and Chile (isolate D1C1) and from apple in New York (NY 358) (data not shown). Isolates identified as $P$. fragariae var. rubi very closely fit the previous descriptions of isolates in this taxon recovered from North America and Europe $(4,5,17,26)$. Distinguishing features were (i) the singleculture production of aplerotic oospores in oogonia with tapered bases, fertilized by antheridia with primarily amphigynous attachments; (ii) nonpapillate, ovoid to obpyriform sporangia on simple sporangiophores; (iii) very slow, poor mycelial growth on CMA and slow but more luxuriant growth on V8RA; and (iv) a maximum temperature for growth of $<28^{\circ} \mathrm{C}$ (Fig. 1).

Morphological and cultural features of the isolates identified as $P$. cryptogea were very similar to those described for isolates of the species recovered from kiwi fruit in Chile and from deciduous fruit trees in California with respect to oospore formation (i.e., oospores formed only in pairings with an $\mathrm{A}_{2}$ mating type of $P$. cinnamomi), sporangium morphology, cardinal temperatures for growth, and colony morphology (9). In addition, subsequent comparisons of six of these raspberry isolates (F5-2, F7-1, F15-2, F17-1, F37-2, and F85) with two of the previously-described kiwi fruit isolates (K-16-0 and A18-3E[04]) yielded similar SDS-PAGE protein profiles and $\mathrm{MDH}$ activities for all. Isolates identified as $P$. gonopodyides produced relatively slowgrowing colonies (maximum 3.5 to 4.0 $\mathrm{mm}$ /day of radial expansion) on CMA and distinctly petalloid colonies on V8RA; had minimum, optimum, and maximum temperatures for growth of 4 to 7, 22 to 28 , and 30 to $33^{\circ} \mathrm{C}$, respectively (Fig. 1); produced nonpapillate sporangia on simple, undifferentiated sporangiophores typical of species in the Group VI of Waterhouse (16); and failed to produce oospores in single culture or when paired with either mating type of $P$. cinnamomi. Such characters conform closely to the recent description (2) of $P$. gonopodyides isolates from aquatic habitats and woody hosts in Britain and North America. These isolates appeared very similar to isolates recovered previously from raspberry and peach in the Great Lakes region of the United States and described as P. cryptogea, either provi- 
sionally (17) or sensu lato (20). They differed strikingly from the isolates identified as $P$. cryptogea in the current study with respect to colony growth rate and morphology, as illustrated previously (9). Examination of the SDS-PAGE protein profiles for six Chilean raspberry isolates of $P$. gonopodyides and four New York fruit crop isolates of $P$. cryptogea sensu lato confirmed a close relationship: similarity coefficients were 60 to 100,55 to 94 , and 40 to 88 for comparisons among Chilean isolates, among New York isolates, and between isolates in the two groups, respectively (Fig. 2).

Geographic distribution of Phytophthora spp. To examine the geographic distribution of the Phytophthora spp. that were recovered, we divided the plantations of origin into three sectors based upon location and associated climatic features. The northern sector (five plantations) extended from Nogales to the metropolitan region surrounding Santiago (approximate southern latitudes of $32^{\circ} 43^{\prime}$ to $33^{\circ} 45^{\prime}$ ); historical weather data (14) from a meteorological station at Quillota $\left(32^{\circ} 53^{\prime} \mathrm{S}\right)$ indicated a mean annual temperature of $15.3^{\circ} \mathrm{C}$, with mean annual rainfall and pan evaporation values of 436 and $1,361 \mathrm{~mm}$, respectively. The central sector (five plantations) extended from San Fernando to Los Angeles (approximate southern latitudes of $34^{\circ} 35^{\prime}$ to $37^{\circ} 23^{\prime}$ ); historical data

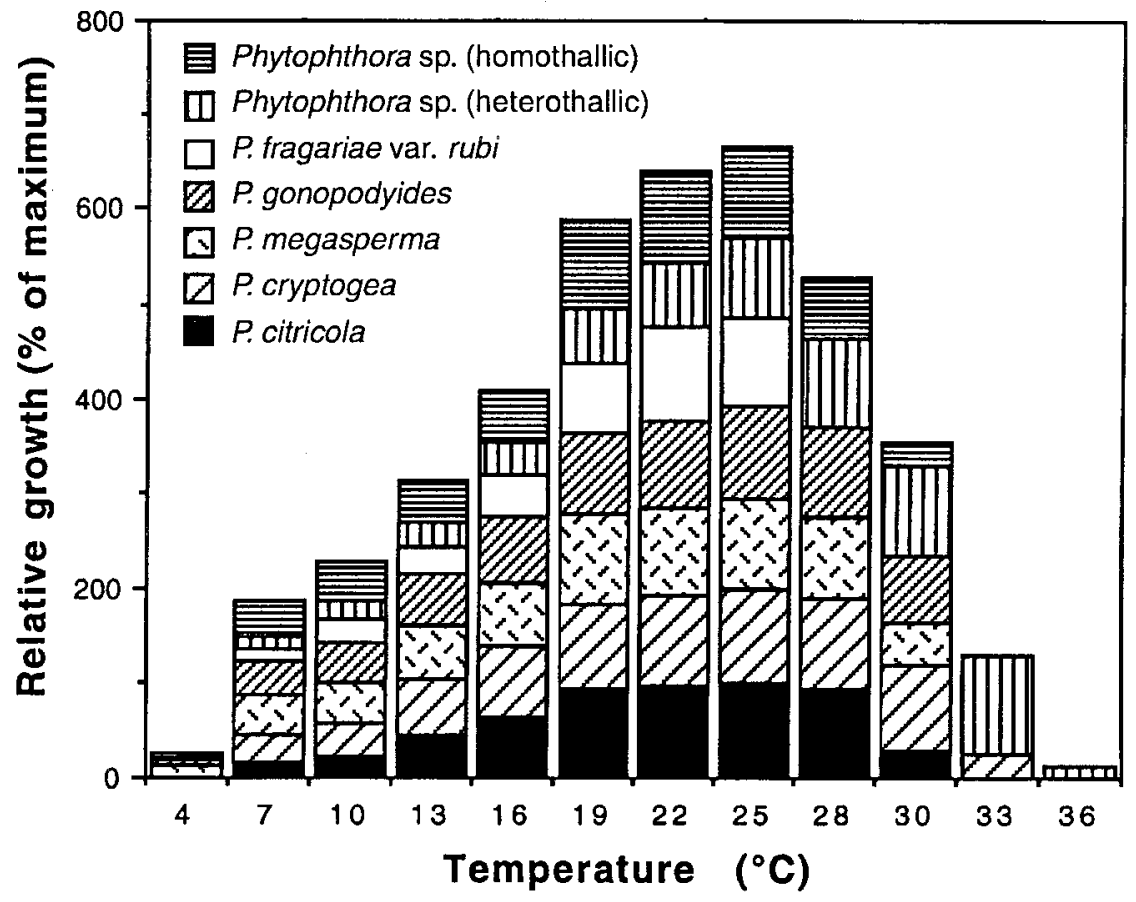

Fig. 1. Effect of temperature on relative mycelial growth of seven Phytophthora spp. recovered from red raspberry plants in Chile. Radial colony expansion on corn meal agar was measured after 5 days at the indicated temperatures for representative isolates of P. citricola $(n=4)$, P. cryptogea $(n=16)$, P. gonopodyides $(n=8)$, P. megasperma $(n=7)$, an unidentified heterothallic Phytophthora sp. $(n=$ 3), and an unidentified homothallic Phytophthora sp. $(n=2)$; similar measurements were made for $P$. fragariae var. rubi isolates $(n=13)$ grown for 9 days on V8-juice agar. For each isolate, growth at the individual temperatures was standardized by calculating it as a percentage of that made at the optimum temperature or temperatures, then a mean for these relative growth values was calculated among all isolates within a given species.

Table 2. Geographical locations of affected red raspberry plantations, cultivars sampled, and the isolation frequencies and identities of the Phytophthora spp. recovered from diseased plants

\begin{tabular}{|c|c|c|c|c|c|}
\hline Sector, region ${ }^{x}$ & Latitude (S) & Plantation $^{\mathrm{y}}$ & Cultivar & Frequency $^{\mathrm{z}}$ & Phytophthora spp. \\
\hline \multicolumn{6}{|l|}{ North } \\
\hline \multirow[t]{3}{*}{$\mathrm{V}$} & $32^{\circ} 43^{\prime}$ & Nogales & Ruby & $0 / 5$ & ... \\
\hline & & $\ldots$ & Heritage & $1 / 3$ & P. cryptogea \\
\hline & $33^{\circ} 05^{\prime}$ & Polpaico & Ruby & $6 / 7$ & P. citricola, $P$. cryptogea \\
\hline \multirow{3}{*}{ Metropolitano } & $33^{\circ} 45^{\prime}$ & Linderos (a) & Heritage & $3 / 3$ & P. cryptogea, Phytophthora sp. (heterothallic) \\
\hline & & Linderos (b) & unknown & $2 / 3$ & P. citricola \\
\hline & $33^{\circ} 45^{\prime}$ & Maipo & Heritage & $1 / 3$ & P. cryptogea \\
\hline \multicolumn{6}{|l|}{ Central } \\
\hline \multirow[t]{2}{*}{ VI } & $34^{\circ} 35^{\prime}$ & San Fernando & Heritage & $3 / 5$ & P. cryptogea, $P$. fragariae var. rubi, $P$. gonopodyides \\
\hline & $34^{\circ} 35^{\prime}$ & Puente Negro & Heritage & $1 / 5$ & P. cryptogea, $P$. megasperma \\
\hline \multirow[t]{2}{*}{ VII } & $35^{\circ} 31^{\prime}$ & San Clemente & Heritage & $3 / 3$ & $P$. fragariae var. rubi, $P$. gonopodyides, $P$. megasperma \\
\hline & $35^{\circ} 48^{\prime}$ & Linares & Heritage & $7 / 7$ & P. cryptogea, $P$. fragariae var. rubi, $P$. gonopodyides \\
\hline \multirow[t]{3}{*}{ VIII } & $37^{\circ} 23^{\prime}$ & Los Angeles & Autumn Bliss & $1 / 1$ & P. fragariae var. rubi \\
\hline & $\ldots$ & Los Angeles & Heritage & $4 / 5$ & $\begin{array}{l}\text { P. citricola, } P \text {. cryptogea } P \text {. fragariae var. rubi, P. gonopody- } \\
\text { ides }\end{array}$ \\
\hline & $\ldots$ & $\ldots$ & Ruby & $2 / 2$ & P. fragariae var. rubi \\
\hline \multicolumn{6}{|r|}{ 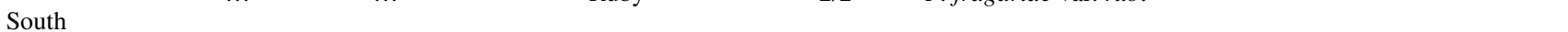 } \\
\hline \multirow[t]{12}{*}{$\mathrm{X}$} & $40^{\circ} 16^{\prime}$ & La Unión (a) & Williamette & $4 / 4$ & P. fragariae var. rubi, $P$. gonopodvides \\
\hline & $\ldots$ & & Heritage & $2 / 3$ & P. citricola, $P$. fragariae var. rubi \\
\hline & $\ldots$ & La Unión (b) & Meeker & $3 / 4$ & P. fragariae var. rubi, $P$. megasperma \\
\hline & $40^{\circ} 17^{\prime}$ & Rio Bueno (a) & Heritage & $2 / 2$ & P. fragariae var. rubi \\
\hline & $\ldots$ & Rio Bueno (b) & Meeker & $3 / 4$ & P. citricola, $P$. fragariae var. rubi \\
\hline & $40^{\circ} 23^{\prime}$ & San Pablo & Heritage & $2 / 2$ & P. megasperma, Phytophthora sp. (homothallic) \\
\hline & & & Meeker & $3 / 4$ & P. megasperma \\
\hline & $40^{\circ} 39^{\prime}$ & Entre Lagos & Meeker & $3 / 3$ & P. gonopodyides, P. megasperma \\
\hline & $40^{\circ} 53^{\prime}$ & Purranque (a) & Meeker & $3 / 3$ & P. fragariae var. rubi, P. megasperma \\
\hline & $\ldots$ & $\ldots$ & Heritage & $1 / 1$ & P. fragariae var. rubi \\
\hline & $\ldots$ & $\ldots$ & Williamette & $1 / 1$ & P. fragariae var. rubi \\
\hline & $\ldots$ & Purranque (b) & Meeker & $2 / 4$ & P. fragariae var. rubi \\
\hline
\end{tabular}

\footnotetext{
${ }^{\mathrm{x}}$ Individual geographical locations were partitioned into northern, central, and southern production sectors based upon climatic differences and governmental administrative regions (designated by Roman numerals).

y Village, town, or city nearest to the indicated plantation; distinct, neighboring plantations are designated (a) and (b).

${ }^{\mathrm{z}}$ Number of plants from which a Phytophthora sp. was isolated/ number of plants sampled.
} 
(14) from Talca $\left(35^{\circ} 26^{\prime} \mathrm{S}\right)$ indicated a mean annual temperature of $14.9^{\circ} \mathrm{C}$, with mean annual rainfall and pan evaporation values of 735 and $1,108 \mathrm{~mm}$, respectively. The southern sector (eight plantations) consisted of the region surrounding Osorno (approximate southern latitudes of $40^{\circ} 16^{\prime}$ to $40^{\circ} 53^{\prime}$ ); historical data (14) from Remehue $\left(40^{\circ} 35^{\prime} \mathrm{S}\right)$ indicated a mean annual temperature of $11.4^{\circ} \mathrm{C}$, with mean annual rainfall and pan evaporation values of 1,383 and $779 \mathrm{~mm}$, respectively.

The array of Phytophthora spp. that were isolated from diseased plants on affected plantations differed greatly with geographical location. For instance, $P$. fragariae var. rubi was recovered from 75 and $60 \%$ of the plantations in the southern and central sectors, respectively, but was not recovered from any plantation in the northern sector. Similarly, P. megasperma and $P$. gonopodyides were recovered from

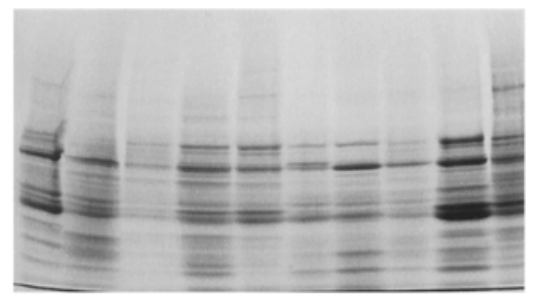

Fig. 2. Sodium dodecyl sulfate-polyacrylamide gel electrophoretic profiles for six Chilean raspberry isolates identified in this study as Phytophthora gonopodyides and for four tree fruit isolates from New York that previously were identified as P. cryptogea sensu lato. From left to right, these isolates were: F35, F4, F45, F87, F83-2, and F63-1, all from raspberry in Chile; NY414 (peach), NY155 (cherry), NY001 (apple), and NY 413 (peach). multiple plantations in the southern and central sectors but were not recovered in the northern sector. In contrast, $P$. cryptogea was recovered from $80 \%$ of the plantations in both the northern and central sectors but not from any plantation in the south, whereas $P$. citricola was isolated from diseased plants in all sectors (Table 2).

Pathogenicity of Phytophthora spp. Field symptoms of infected plants sometimes were characteristic of the particular Phytophthora spp. that were recovered from them. For example, young primocanes infected with $P$. fragariae var. rubi typically were very stunted, had small leaves that were off-colored or scorched, and often showed a dark water-soaked lesion advancing up the succulent stem from beneath the soil line (Fig. 3B). No other Phytophthora spp. were isolated from plants exhibiting these symptoms. In contrast, $P$. megasperma often was isolated from plants that had died in sharply demarcated patches where excessive water appeared to have accumulated (Fig. 3A). P. gonopodyides also sometimes was isolated from plants in such excessively wet locations, but it was less consistently associated with these or any other unique symptoms. Similarly, $P$. citricola and $P$. cryptogea were not associated with any unique symptoms beyond a general dieback and associated root rot (8).

All tested isolates of $P$. cryptogea, $P$. citricola, and the unidentified heterothallic Phytophthora sp. killed each of the five replicate plants in each of the three greenhouse pathogenicity trials (Table 3 ). However, pathogenicity and virulence of the other Phytophthora spp. varied among experiments. For example, the four $P$. fragariae var. rubi isolates examined in experiment 2 (average maximum soil temperature of $19.5^{\circ} \mathrm{C}$ ) each killed all five replicate plants, and the four isolates examined in experiment 3 (average maximum soil temperature of $21.9^{\circ} \mathrm{C}$ ) cumulatively killed 14 of 20 plants and caused a mean root rot severity of $96 \%$. In contrast, however, the three of these isolates tested in experiment 1 (average maximum soil temperature of $27.5^{\circ} \mathrm{C}$ ), each of which was in experiment 3 , caused a mean root rot severity of only $48 \%$ and cumulatively killed only 4 of 15 plants (Table 3 ). Similarly, $P$. megasperma was highly virulent in experiment 3 but only weakly virulent or nonpathogenic in experiment 1 , whereas the virulence of $P$. gonopodyides ranged from high in experiment 3 to moderate in experiment 1 to low in experiment 2, with some variation among the two isolates tested (Table 3).

\section{DISCUSSION}

Although P. citricola and P. citrophthora have been implicated previously as causal agents of raspberry root rot in Chile (8), we consistently recovered four additional recognized Phytophthora spp. from dead and dying raspberry plants in various parts of the country and confirmed the pathogenicity of representative isolates of each. Whereas each of these additional species has been shown to cause disease on raspberries in other parts of the world (18), $P$. cryptogea is the only one previously reported as a pathogen of raspberries in the Southern Hemisphere (15).

The expansive north-south orientation of Chile provided a unique opportunity to
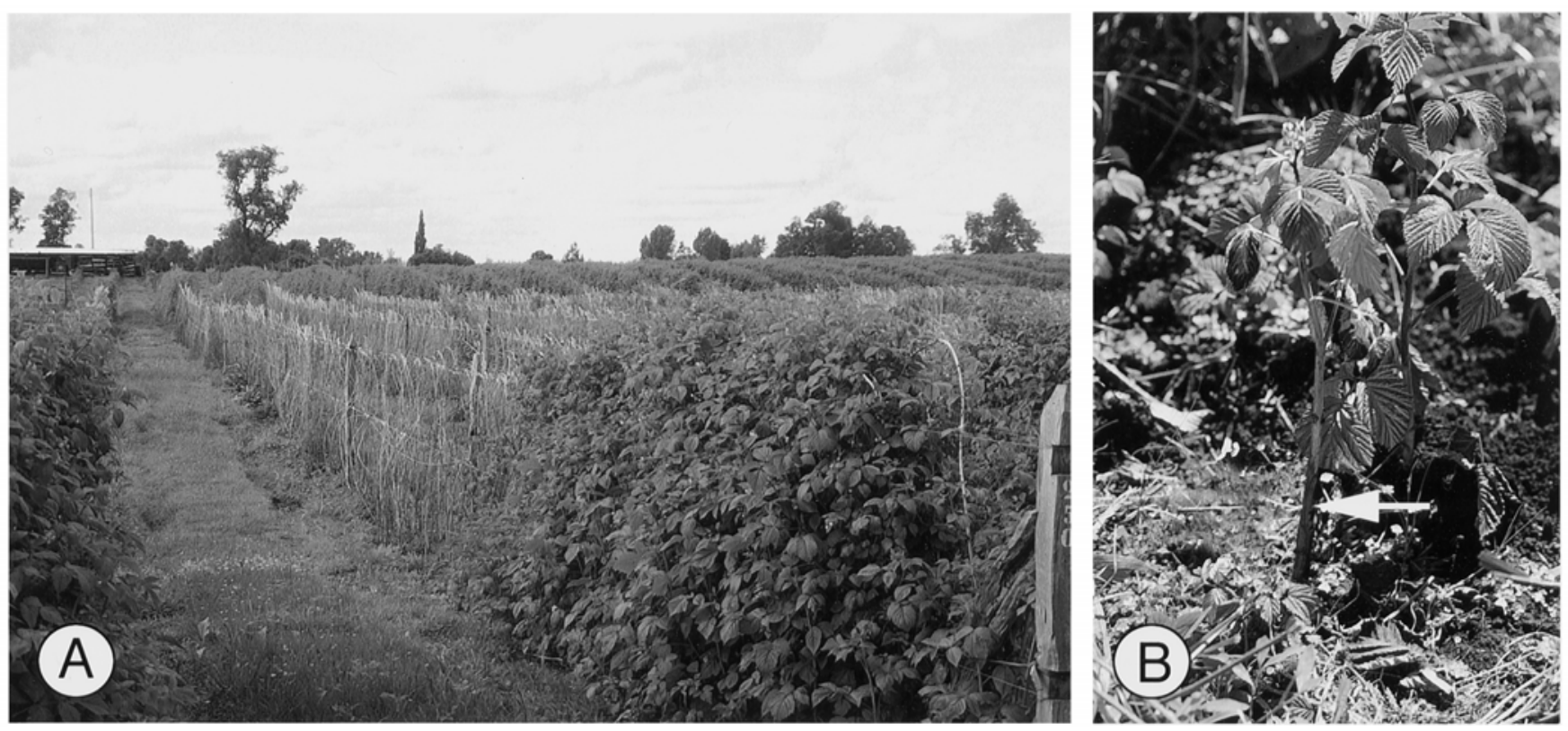

Fig. 3. Distinctive field symptoms of two Phytophthora spp. causing root rot of raspberry in southern Chile. A, Sharply defined zone of dead 'Meeker' raspberries infected with $P$. megasperma, in association with an apparent accumulation of excessive water. B, Typical symptoms on a 'Heritage' primocane infected with P. fragariae var. rubi. Note dark, watersoaked lesion at the base of the cane (arrow), accompanied by severe stunting, premature cessation of terminal growth, and reduced size and scorching of leaves. 
study the distribution of different Phytophthora spp. on this single host in a diverse range of geographical locations and corresponding climates. Our sampling program did not systematically include all raspberry-producing districts in the country. Indeed, omission of several plantations established in old citrus orchards surrounding Santiago and in the nearby VI region, where $P$. citrophthora previously was isolated (8; B. A. Latorre, unpublished), may have accounted for our failure to detect this species in the present study. Nevertheless, distinct distribution patterns emerged. For example, $P$. fragariae var. rubi, a species that failed to grow at temperatures $>25^{\circ} \mathrm{C}$ (Fig. 1), was not detected in the northern production sector where temperatures and evapotranspirative demand are higher and rainfall is lower than in the central and southern production sectors. Similarly, $P$. megasperma, a species that appears to require very wet soils $(12,17,19,22,24)$ and temperatures $<25^{\circ} \mathrm{C}(23)$ in order to cause significant disease on deciduous fruit crops, was isolated frequently in the cool and wet southern sector, less so in the central sector, and not at all in the northern- most region. Consistent with these observations, the virulence of both species in greenhouse trials appeared considerably lower in experiment 1 , where soil temperatures were the highest, than in other experiments, where soil temperatures were more moderate (Table 2). P. gonopodyides, a species that has been reported primarily from Britain and northwestern North America (2) and from the relatively cool and wet Great Lakes region of the United States (where it previously has been identified as $P$. cryptogea; $1,13,17,20)$, also was detected only in the southern and central sectors of Chilean raspberry production. In contrast, isolates that we identified as $P$. cryptogea, which appeared very similar to $P$. cryptogea isolates recovered from deciduous fruit trees in California and from kiwi fruit in Chile (where it has been isolated exclusively in latitudes corresponding to the northern and central raspberry sectors; B. A. Latorre, unpublished), were not recovered from the southern raspberry sector. However, such isolates were highly virulent under all greenhouse test conditions, and the reasons for the aforementioned distribution pattern are unclear.

Table 3. Root rot severity and mortality incidence for 'Heritage' red raspberry plants grown for 12 to 16 weeks in potting medium artificially infested with isolates of Phytophthora spp. recovered from symptomatic raspberry plants in Chile ${ }^{\mathrm{w}}$

\begin{tabular}{|c|c|c|c|c|c|c|}
\hline \multirow[b]{2}{*}{ Species, isolate } & \multicolumn{2}{|c|}{ Experiment $1^{\mathrm{x}}$} & \multicolumn{2}{|c|}{ Experiment $2^{y}$} & \multicolumn{2}{|c|}{ Experiment $3^{z}$} \\
\hline & Root rot (\%) & Dead & Root rot $(\%)$ & Dead & Root rot $(\%)$ & Dead \\
\hline \multicolumn{7}{|l|}{ P. citricola } \\
\hline F21-1 & $100 \mathrm{a}$ & $5 / 5$ & $100 \mathrm{a}$ & $5 / 5$ & $100 \mathrm{a}$ & $5 / 5$ \\
\hline F75-1 & $100 \mathrm{a}$ & $5 / 5$ & $100 \mathrm{a}$ & $5 / 5$ & $100 \mathrm{a}$ & $5 / 5$ \\
\hline \multicolumn{7}{|l|}{ P. cryptogea } \\
\hline F7-1 & $100 \mathrm{a}$ & $5 / 5$ & $100 \mathrm{a}$ & $5 / 5$ & $100 \mathrm{a}$ & $5 / 5$ \\
\hline F17-1 & $100 \mathrm{a}$ & $5 / 5$ & $100 \mathrm{a}$ & $5 / 5$ & $100 \mathrm{a}$ & $5 / 5$ \\
\hline F25-2 & $100 \mathrm{a}$ & $5 / 5$ & $100 \mathrm{a}$ & $5 / 5$ & $100 \mathrm{a}$ & $5 / 5$ \\
\hline F77-2 & $100 \mathrm{a}$ & $5 / 5$ & $100 \mathrm{a}$ & $5 / 5$ & $100 \mathrm{a}$ & $5 / 5$ \\
\hline F80 & $100 \mathrm{a}$ & $5 / 5$ & $100 \mathrm{a}$ & $5 / 5$ & $100 \mathrm{a}$ & $5 / 5$ \\
\hline F84 & $100 \mathrm{a}$ & $5 / 5$ & $100 \mathrm{a}$ & $5 / 5$ & $100 \mathrm{a}$ & $5 / 5$ \\
\hline \multicolumn{7}{|c|}{ P. fragariae var. rubi } \\
\hline F3 & $54 \mathrm{c}$ & $2 / 5$ & $100 \mathrm{a}$ & $5 / 5$ & $94 \mathrm{~b}$ & $3 / 5$ \\
\hline F42-1 & $68 \mathrm{bc}$ & $2 / 5$ & $100 \mathrm{a}$ & $5 / 5$ & $91 \mathrm{~b}$ & $2 / 5$ \\
\hline F54 & $22 \mathrm{de}$ & $0 / 5$ & & & $100 \mathrm{a}$ & $5 / 5$ \\
\hline F58 & $\ldots$ & $\ldots$ & $100 \mathrm{a}$ & $5 / 5$ & $\ldots$ & $\ldots$ \\
\hline F71 & $\ldots$ & $\ldots$ & $100 \mathrm{a}$ & $5 / 5$ & $100 \mathrm{a}$ & $5 / 5$ \\
\hline \multicolumn{7}{|l|}{ P. gonopodyides } \\
\hline $\mathrm{F} 4$ & $32 \mathrm{~d}$ & $1 / 5$ & $7 \mathrm{c}$ & $0 / 5$ & $100 \mathrm{a}$ & $5 / 5$ \\
\hline F33-2 & $66 \mathrm{~b}$ & $2 / 5$ & $43 \mathrm{~b}$ & $1 / 5$ & $100 \mathrm{a}$ & $5 / 5$ \\
\hline \multicolumn{7}{|l|}{ P. megasperma } \\
\hline F55 & $18 \mathrm{def}$ & $0 / 5$ & $\ldots$ & $\ldots$ & $100 \mathrm{a}$ & $5 / 5$ \\
\hline F65-2 & $28 \mathrm{~d}$ & $0 / 5$ & $\ldots$ & $\ldots$ & $100 \mathrm{a}$ & $5 / 5$ \\
\hline \multicolumn{7}{|l|}{ Phytophthora sp. } \\
\hline F $24-2$ & $100 \mathrm{a}$ & $5 / 5$ & $100 \mathrm{a}$ & $5 / 5$ & $100 \mathrm{a}$ & $5 / 5$ \\
\hline \multicolumn{7}{|l|}{ Heterothallic } \\
\hline F26-3 & $100 \mathrm{a}$ & $5 / 5$ & $100 \mathrm{a}$ & $5 / 5$ & $100 \mathrm{a}$ & $5 / 5$ \\
\hline \multicolumn{7}{|l|}{ Check } \\
\hline Flooded & 5 ef & $0 / 5$ & $5 \mathrm{c}$ & $0 / 5$ & $22 \mathrm{~d}$ & $0 / 5$ \\
\hline Nonflooded & $2 \mathrm{f}$ & $0 / 5$ & $3 \mathrm{c}$ & $0 / 5$ & $5 \mathrm{c}$ & $0 / 5$ \\
\hline
\end{tabular}

${ }^{\mathrm{w}}$ Colonized-vermiculite inoculum of each indicated isolate was incorporated into pasteurized soilvermiculite potting medium at a rate of $2 \%(\mathrm{vol} / \mathrm{vol})$ immediately before healthy plants were transplanted therein. All plants (except nonflooded checks) were flooded for a 48 -h period 2 weeks later and at 2-week intervals thereafter. Values represent the means for five replicate plants per treatment. Means within a column not followed by a common letter are significantly different $(P=0.05)$ according to the Waller-Duncan $k$-ratio $t$ test; $\ldots=$ isolate not included in this experiment.

${ }^{x}$ Experiment conducted in a greenhouse in Geneva, NY from 17 June to 5 October 1994.

y Experiment conducted in a greenhouse in Geneva, NY from 19 Dec 1994 to 12 April 1995.

${ }^{\mathrm{z}}$ Experiment conducted in a greenhouse in Geneva, NY from 13 April to 29 June 1995.
Isolates that we identified as $P$ gonopodyides were very similar to isolates from deciduous fruit trees in New York that previously were identified as $P$. cryptogea sensu lato with respect to colony type, growth responses to temperature, sporangial morphology, and electrophoretic banding patterns of soluble mycelial proteins. However, several studies $(2,9,13)$ have concluded that these same New York isolates (and other similar isolates from fruit crops in the broader Great Lakes region) show little relatedness to other recognized groups of $P$. cryptogea (or $P$. drechsleri), suggesting that they probably belong to a distinct but heretofore unspecified taxon. Recently, Brasier et al. (2) closely examined a number of isolates from northwestern North America which originally had been identified as $P$. drechsleri and reclassified them as $P$. gonopodyides. They noted that this latter species has received "remarkably" little attention in the literature and can be difficult to identify on morphological grounds alone, but included slow mycelial growth and a distinctively petalloid colony pattern as useful distinguishing characteristics. On the basis of isozyme and mitochondrial DNA analysis, Mills et al. (13) previously had placed several of the isolates thus reclassified by Brasier et al. (i.e., isolate numbers 133, 139, and 266) into their own groups $\mathrm{J}$ and $\mathrm{K}$ of $P$. cryptogea, along with all four of the New York "P. cryptogea" isolates examined in this current study, plus others that we have characterized previously (9). The authors noted the distinctiveness of these groups with respect to others in the species, in terms of not only their molecular characteristics but also their colony morphologies and growth rates. Thus, because the New York isolates previously identified as $P$. cryptogea clearly do not belong in this taxon but appear to be conspecific with at least some isolates that have been reclassified as $P$. gonopodyides, we believe that it is appropriate to reclassify them within this latter taxon, sensu Brasier et al. (2). Similarly, we also believe it appropriate to assign Chilean raspberry isolates that share cultural, morphological, and protein profile characteristics with these New York isolates to the same taxon. However, the possible polyphyletic nature of $P$. gonopodyides and other taxonomic caveats raised by Brasier et al. (2) should be recognized.

Our study did not attempt to identify the origin of the Phytophthora spp. that we isolated. However, it is interesting to note that, at one site in the southern sector, the only plants showing foliar symptoms of root rot were in a small patch recently established with propagating material from a neighboring plantation, and that $P$. fragariae var. rubi was isolated from diseased plants at both sites. Although ours was an anecdotal observation, there is ample evidence that this pathogen has been distrib- 
uted widely via contaminated propagating material (4), and managers of plantations free of the pathogen should strive to avoid introducing it by this or other means. Furthermore, whereas judicious water management and raised-bed planting systems can help to minimize this disease $(7,11,25)$, we noted unusual occurrences where cultural practices appeared to exacerbate its severity by promoting wet soils (e.g., planting in irrigation furrows or converting established flat beds into raised beds by mounding excessive soil [40 to $50 \mathrm{~cm}$ high] prior to new cane emergence). However, we also noted other plantations where the disease was not apparent or was being held to manageable levels via careful irrigation or registered fungicide applications. Finally, cultivar selection in Chile historically has been based almost entirely on fruit quality and other market considerations, but genetic resistance to root rot probably should be considered also, especially in wetter locations (25).

\section{ACKNOWLEDGMENTS}

We thank J. A. Burr, J. R. Nevill, and R. Torres for their technical assistance.

\section{LITERATURE CITED}

1. Bielenin, A., Jeffers, S. N., Wilcox, W. F., and Jones, A. L. 1988. Separation by protein electrophoresis of six species of Phytophthora associated with deciduous fruit crops. Phytopathology 78:1402-1408.

2. Brasier, C. M., Hamm, P. B., and Hansen, E. M. 1993. Cultural characters, protein patterns and unusual mating behavior of Phytophthora gonopodyides isolates from Britain and North America. Mycol. Res. 97:1287-1298.

3. Coffey, M. D., and Bower, L. A. 1984. In vitro variability among isolates of eight Phytophthora species in response to phosphorous acid. Phytopathology 74:738-742.

4. Duncan, J. M., Kennedy, D. M., and Scott, P. H. 1991. Relationships between non-papillate, soilborne species of Phytophthora: root rot of raspberry. Pages 129-147 in: Phytophthora. J. A. Lucas, R. C. Shattock, D. S. Shaw, and L. R. Cooke, eds. Cambridge University Press, Cambridge, UK.

5. Duncan, J. M., Kennedy, D. M., and Seemüller, E. 1987. Identities and pathogenicities of Phytophthora spp. causing root rot of red raspberry. Plant Pathol. 36:276-289.

6. Hansen, E. M., Brasier, C. M., Shaw, D. S., and Hamm, P. B. 1986. The taxonomic structure of Phytophthora megasperma: Evidence for emerging biological species groups. Trans. Br. Mycol. Soc. 87:557-574.

7. Heiberg, N. 1995. Control of root rot of red raspberries caused by Phytophthora fragariae var. rubi. Plant Pathol. 44:153-159.

8. Latorre, B. A., and Muñoz, R. 1993. Root rot of red raspberry caused by Phytophthora $c i$ tricola and $P$. citrophthora in Chile. Plant Dis. 77:715-718.

9. Latorre, B. A., Pérez, G. F., Wilcox, W. F., and Torres, R. 1995. Comparative protein electrophoretic and isozymic patterns of Phytophthora cryptogea isolates from Chilean kiwifruit and North American deciduous fruits. Plant Dis. 79:703-708.

10. Latorre, B. A., and Wilcox, W. F. 1996. Deteccíon de Phytophthora spp. en árboles frutales por análisis immunológicos. Fitopatología 31:202-206.

11. Maloney, K., Wilcox, W. F., and Sanford, J. C. 1993. Effects of raised beds and metalaxyl for control of Phytophthora root rot of raspberry. HortScience 28:1106-1108.

12. Merwin, I. A., Wilcox, W. F., and Stiles, W. C. 1992. Influence of orchard ground-cover management on the development of Phytophthora crown and root rots of apple. Plant Dis. 76:199-205.

13. Mills, S. D., Förster, H., and Coffey, M. D. 1991. Taxonomic structure of Phytophthora cryptogea and $P$. drechsleri based on isozyme and mitochondrial DNA analyses. Mycol. Res. 92:31-48.

14. Novoa, R., and Villaseca, S., eds. 1989. Mapa Agroclimatico de Chile. Instituto de Investigaciones Agropecuarias, Santiago, Chile.

15. Washington, W. S. 1988. Phytophthora cryptogea as a cause of root rot of raspberry culti- vars and control with fungicides. Plant Pathol. 37:255-30.

16. Waterhouse, G. M. 1963. Key to the species of Phytophthora de Bary. Mycol. Paper No. 92. Commonw. Mycol. Inst. Kew, Surrey, UK.

17. Wilcox, W. F. 1989. Identity, virulence, and isolation frequency of seven Phytophthora spp. causing root rot of red raspberry in New York. Phytopathology 79:93-101.

18. Wilcox, W. F. 1991. Phytophthora root rot Pages 34-36 in: Compendium of Raspberry and Blackberry Diseases and Insects. M. A Ellis, R. H. Converse, R. N. Williams, and B. Williamson, eds. American Phytopathological Society Press, St. Paul, MN.

19. Wilcox, W. F. 1993. Incidence and severity of crown and root rots on four apple rootstocks following exposure to Phytophthora species and waterlogging. J. Am. Soc. Hortic. Sci. 118:63-67.

20. Wilcox, W. F., and Ellis, M. A. 1989. Phytophthora root and crown rots of peach trees in the eastern Great Lakes region. Plant Dis. 73:794-798.

21. Wilcox, W. F., and Latorre, B. A. 1995. Identity and distribution of Phytophthora spp causing root rot of raspberry in Chile. (Abstr.) Phytopathology 85:1150.

22. Wilcox, W. F., and Mircetich, S. M. 1985. Effects of flooding duration on the development of Phytophthora root and crown rots of cherry. Phytopathology 75:1451-1455.

23. Wilcox, W. F., and Mircetich, S. M. 1987. Lack of host specificity among isolates of Phytophthora megasperma. Phytopathology 77:1132-1137.

24. Wilcox, W. F., Nevill, J. R., and Burr, J. A. 1999. Susceptibility of red, black, and purple raspberry cultivars to three Phytophthora species under greenhouse and field conditions. Acta Hortic. 505:241-247.

25. Wilcox, W. F., Pritts, M. P., and Kelly, M. J. 1999. Integrated control of Phytophthora root rot of red raspberry. Plant Dis. 83:1149. 1154.

26. Wilcox, W. F., Scott, P. H., Hamm, P. B., Kennedy, D. M., Duncan, J. M., Brasier, C. M., and Hansen, E. M. 1993. Identity of a Phytophthora species attacking raspberry in Europe and North America. Mycol. Res 97:817-831. 